\title{
IAMJ
}

INTERNATIONAL

AYURVEDIC

MEDICAL JOURNAL

\section{PHARMACEUTICAL STUDY OF TRIBHUVANKIRTI RASA: A HERBOMINERAL FORMULATION}

\author{
$\underline{\text { Kirti B. Tikhat }}^{1}$, Ganesh S. Tekale ${ }^{2}$ \\ PG scholar, dept. Of RSBK, GAC, Nagpur, Maharashtra, India \\ Associate Professor, Dept Of RSBK, GAC, Nagpur, Maharashtra, India
}

Corresponding Author: k.tikhat@gmail.com

\section{https://doi.org/10.46607/iamj0109122021}

(Published Online: December 2021)

Open Access

(C) International Ayurvedic Medical Journal, India

Article Received: 06/10//2021 - Peer Reviewed: 30/10/2021 - Accepted for Publication 31/10/2021

\section{Check for updates}

\section{ABSTRACT}

Tribhuvankirti means familiar in three lokas i.e. Akash, Patal, Pruthvi. The disease which persists at the time of birth and death is Jwara. Tribhuvankirti Rasa is the most efficacious herbomineral ayurvedic drug widely prescribed by physicians for the treatment of different types of Jwara especially Sannipataj Jwara. It is a Kharaliya Rasayana which contains Hingula, Vatsanabha, Trikatu, Tankan, Pippalimoola and Bhavana of Tulsi Patra Swaras, Ardrak Swaras and Dhattur Patra Swaras. In this paper, pharmaceutical aspects of Tribhuvankirti Rasa prepared by the reference of Yogaratnakar are discussed i.e. detailed pharmaceutical procedures adopted for the preparation of Tribhuvankirti Rasa have been discussed such as Vatsanabha Shodhan, Hingul Shodhan, etc. This study will serve as a guide for those who want to reproduce Tribhuvankirti Rasa in future that provide them with the details on what has to be done at each step of production.

Keywords: Tribhuvankirti Rasa, Hingul, Tankan, Borax, herbomineral preparation. 


\section{INTRODUCTION}

The one of the oldest systems of medicine, Ayurveda is momentous in audience of worldwide on virtue of its holistic approach of life. Formulations of Ayurveda consist of substances of herbal, mineral/ metal and animal origin which are processed pharmaceutically to have therapeutic effects. This is attribute of processes of Shodhan, Bhavana and Maran of Rasashastra which acclimatize this toxic industrial matter to an effective remedy known as herbomineral formulations (Rasaushadhis) of Ayurveda. ${ }^{[1]}$ Tribhuvankirti Rasa is one of the herbomineral formulation. Tribhuvankirti means familiar in three lokas i.e., Akash, Patal, Pruthvi. The disease which persists at the time of birth and death is Jwara. In AyurvedaJwara is given topmost importance because it is believed that Jwara is the first disease to trouble mankind and it becomes the basic for other diseases to exist. Many types of Jwara are explained by our Acharyas. Tribhuvankirti Rasa is the most efficacious herbomineral ayurvedic drug widely prescribed by physicians for the treatment of different types of $J w a-$ ra especially Sannipataj Jwara. It is a Kharaliya $R a$ sayana which contains Hingula, Vatsanabha, Trikatu, Tankan, Pippalimoola and Bhavana of Tulsi Patra Swaras, Ardrak Swaras and Dhattur Patra Swaras. ${ }^{[2]}$ In this paper, pharmaceutical aspects of Tribhuvankirti Rasa prepared by the reference of Yogaratnakar are discussed i.e., detailed pharmaceutical procedures adopted for the preparation of Tribhuvankirti Rasa have been discussed such as Vatsanabha Shodhan, Hingul Shodhan, etc.

AIM:

- To study the procedure of Shodhana of Hingula, Tankan and Vatsanabha.

- Preparation of Tribhuvankirti Rasa according to Yogaratnakar.

\section{MATERIAL AND METHODS:}

\section{This consists of:}

Drug Review; Hingul Shodhan; Tankan Shodhan; Vatsanabha Shodhan; Preparation of Tribhuvankirti Rasa with the reference of Yogaratnakar.

\section{Drug Review:}

Table 1.1: Showing review of mineral drugs

\begin{tabular}{|c|c|c|}
\hline Drug Name & Hingula $^{[3]}$ & Tankan ${ }^{[4]}$ \\
\hline Chemical Name & Red oxide of mercury & Borax \\
\hline Chemical formula & $\mathrm{HgS}$ & $\mathrm{Na} 2 \mathrm{~B} 4 \mathrm{O} 7,10 \mathrm{H} 2 \mathrm{O}$ \\
\hline Rasa & Tikta, Kashay, Katu & Katu \\
\hline Doshaghnata & Tridoshahar & Vatakaphaghna \\
\hline Karya & $\begin{array}{l}\text { Jwaraghna, Aampachan, Atirasayan, } \\
\text { Vishanashak }\end{array}$ & $\begin{array}{l}\text { Kaphavishleshak, Hridya, Sthavar } \\
\text { vishanashak, Agnideepak }\end{array}$ \\
\hline
\end{tabular}

Table 1.2: Showing review of herbal drugs

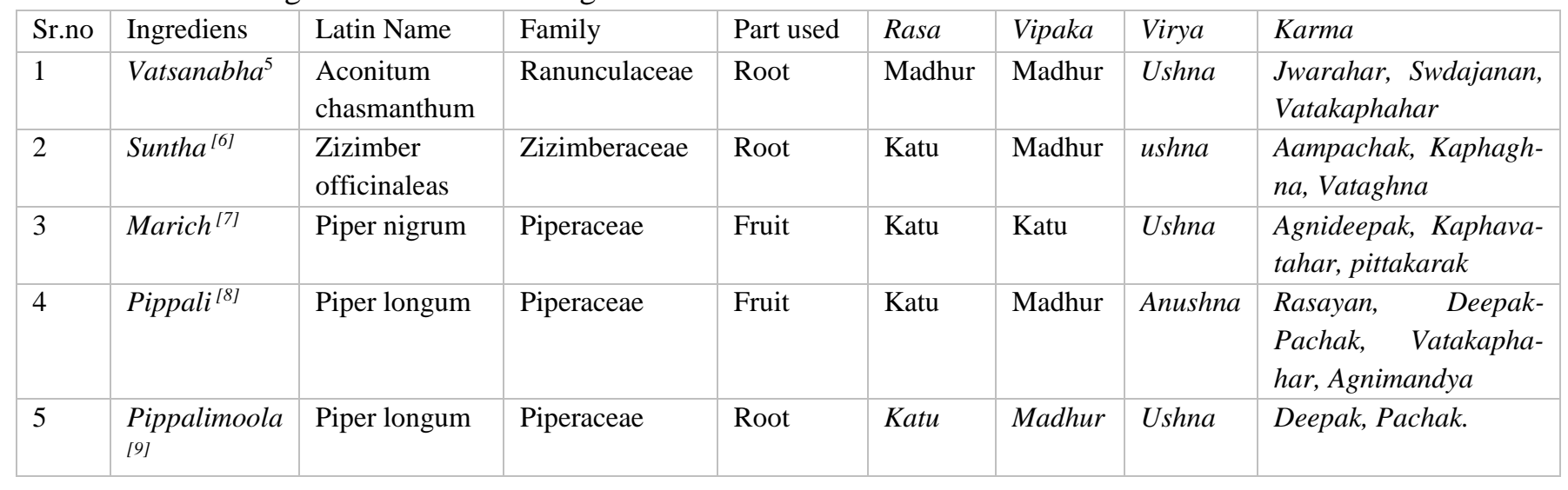


Table 1.3: Showing Drug review of Bhavana Dravya

\begin{tabular}{|l|l|l|l|l|l|l|l|l|}
\hline $\begin{array}{l}\text { Sr. } \\
\text { No }\end{array}$ & $\begin{array}{l}\text { Drug } \\
\text { name }\end{array}$ & Latin Name & Family & $\begin{array}{l}\text { Part } \\
\text { used }\end{array}$ & Rasa & Vipaka & Virya & Karma \\
\hline 1 & Tulsi ${ }^{[10]}$ & $\begin{array}{l}\text { Ocimum } \\
\text { sanctum }\end{array}$ & Lamiaceae & Leaf & Katu, Tikta & Katu & Ushna & Kaphavatashamak \\
\hline 2 & $\begin{array}{l}\text { Ardrak } \\
{[6]}\end{array}$ & $\begin{array}{l}\text { Zizimber } \\
\text { officinale }\end{array}$ & Zizimberaceae & Rhizome & Katu & Katu & Ushna & $\begin{array}{l}\text { Agnideepan, Kaphava- } \\
\text { tashamak }\end{array}$ \\
\hline 3 & $\begin{array}{l}\text { Dhattur } \\
{[11]}\end{array}$ & $\begin{array}{l}\text { Dhatura } \\
\text { metel }\end{array}$ & Solanaceae & Leaf & $\begin{array}{l}\text { Kashay, } \\
\text { Madhur, Tikta }\end{array}$ & Katu & Ushna & $\begin{array}{l}\text { Kaphavatahar } \\
\text { Prabhav-Madakari }\end{array}$ \\
\hline
\end{tabular}

2. Hingul Shodhan: ${ }^{[12]}$

$>$ Ref- R.T. $9 / 12$

$>$ Apparatus: Khalva yantra, measuring jar

$>$ Ingredients:

- Ashuddha Hingula: 50gms

- Ardrak swaras: Q.S.

$>$ Procedure:

- Ashuddha Hingula was taken in a Khalvayantra and made fine powder of it.

- Required quantity of Ardrak swaras was added in it and mardan was done till it dried.

- In this was way, 7 bhavanas were given.

- Shuddha Hingula was stored in a glass bottle.

Result:

$>$ Quantity taken- 50gms

$>$ Quantity obtained-55gms

$>$ Gain in wt.- 5 gms

3. Tankan Shodhan ${ }^{[13]}$

$>$ Type of Shodhan - Utphullikaran

$>$ Reference - R.T. 13-77,78

$>$ Equipments: Pan, Spoon, Gas

\section{$>$ Procedure:}

Fine powder of tankan was heated with continuous stirring; till it became white porous mass and crackling sound disppears.

\section{$>$ Precaution:}

Heating should be done on Mandagni.

\section{Result:}

- Quantity taken: 100gms

- Quantity obtained: 75gms

- Loss: $25 \mathrm{gms}$ due to evaporation of water molecules

4. Vatsanabha Shodhan: ${ }^{[14]}$

$>$ Ref: R.T.24/19-22

$>$ Apparatus: Mrittika patra, knife, measuring jar

$>$ Procedure:

- Vatsanabha was taken and cut it into small pieces equal to gram.

- These pieces of Vatsanabha will put in a Mrittika patra, fill fresh cow urine in it.

- Mrittika patra was kept in strong sunlight.

- Every morning taken out the old cow urine and then at the same time fresh cow urine was added in it and was put in sunlight.

- Same procedure was repeated for 7 days.

- After 7 days, pieces of Vatsanabha were taken out of the urine and washed with warm water.

- Then outer skin was separated by peeling it with a knife and it was dried in sunlight.

- Then Swedan in Godugdha by Dolayantra method was done for $3 \mathrm{hrs}$. And then washed with water.

- Then dried in sunlight and fine powder was made. 


\section{Observations}

Table 4.1: Showing observations regarding Vatsanabha Shodhan

\begin{tabular}{|l|l|l|l|}
\hline Sr. No. & Organoleptic characters & Before shodhana & After shodhana \\
\hline 1 & Shabda & - & - \\
\hline 2 & Sparsha & Khara, kathin & Mrudu, \\
\hline 3 & Rupa & Externally brown (Gostanakara) & Internally creamish \\
\hline 4 & Rasa & - & - \\
\hline 5 & Gandha & Nirgandha & Slight gomutragandhi \\
\hline
\end{tabular}

\section{Result:}

Table 4.2: Showing result of Vatsanabha Shodhan

Raw Vatsanabha Taken- 100 gm

Vatsanabha Churna Obtained- 38 gm

\section{Preparation of Tribhuvankirti Rasa according to Yogaratnakar \\ $>$ Apparatus:}

Khalvayantra, Spoon, Cloth, Measuring jar.

\section{$>$ Ingredients:}

1. Shuddha Hingula $-21.5 \mathrm{gm}$

2. Shuddha Vatsanabha - $21.5 \mathrm{gm}$

3. Shuddha Tankan $-21.5 \mathrm{gm}$

4. Suntha $-21.5 \mathrm{gm}$

5. Maricha $-21.5 \mathrm{gm}$

6. Pippali - 21.5gm

7. Pippalimula - 21.5gm

Bhavana: 3-3 bhavana of Tulasipatra swaras, Ardrak swaras, Dhattur Patra swaras

\section{$>$ Procedure:}

- Firstly, Shuddha hingula was taken in Khalvayantra (mortar and pestle) and mardana (trituration) was done.

- Then Shuddha Vatsanabha (purified aconite) was added in it and mardana was done.

- Then Suntha Churna, Maricha Churna, pippali Churna were added sequentially one by one, and trituration was done after adding each Churna till it get mixed properly.

- Then Tulasi Swaras was added in sufficient quantity such that the above mixture gets completely immersed and Mardan (trituration) was done till it gets completely dried.

- In this way, 3 Bhavana of Tulasi patra swaras, 3 Bhavana of Ardrak Swaras, 3 Bhavana of Dhattura Swaras were given.

- Then vatis were made of approximately $125 \mathrm{mg}$ each.

- Vatis (pills) were allowed to dry and then packed in airtight container.

\section{OBSERVATIONS:}

Table 5.1: Showing observations of each Bhavana

\begin{tabular}{|l|l|l|l|l|l|}
\hline Sr.no. & Bhavana Dravya & Quantity & Rupa & Gandha & Sparsha \\
\hline 1 & $\begin{array}{l}\text { Tulsi patra swaras } \\
\text { (Juice of holy basil) }\end{array}$ & $200 \mathrm{ml}$ & reddish & Smell of tulasi patra & Mrudu(soft) \\
\hline 2 & Tulsi patra swaras & $190 \mathrm{ml}$ & Greenish red & - & - \\
\hline 3 & Tulsi patra swaras & $190 \mathrm{ml}$ & Greenish red & - & $\begin{array}{l}\text { Mrudu, Shlakshna, Particle size became } \\
\text { less and feel Sukshmatva on touch. }\end{array}$ \\
\hline 4 & $\begin{array}{l}\text { Ardrak swaras } \\
\text { (Ginger juice) }\end{array}$ & $190 \mathrm{ml}$ & Brick red & $\begin{array}{l}\text { Smell of tulsi and } \\
\text { Ardrak swaras }\end{array}$ & - \\
\hline 5 & Ardrak swaras & $180 \mathrm{ml}$ & Brick red & - & $\begin{array}{l}\text { Mrudu (soft), Shlaksha, Particle size } \\
\text { decreases further and feel more } \\
\text { Sukshmatva (fineness) on touch. }\end{array}$ \\
\hline 6 & Ardrak swaras & $180 \mathrm{ml}$ & Brick red & - & \\
\hline
\end{tabular}




\begin{tabular}{|l|l|l|l|l|l|}
\hline 7 & $\begin{array}{l}\text { Dhattur Patra Swa- } \\
\text { ras (juice of Dhatura } \\
\text { metel) }\end{array}$ & $170 \mathrm{ml}$ & Brownish & $\begin{array}{l}\text { Smell of dhattur } \\
\text { patra and ardrak }\end{array}$ & \\
\hline 8 & Dhattur patra swaras & $170 \mathrm{ml}$ & Brownish & - & Mrudu, Shlakshna, Particle size became \\
\hline 9 & Dhattur patra swaras & $170 \mathrm{ml}$ & Brownish & - & $\begin{array}{l}\text { very very less and feel more Sukshmatva } \\
\text { on touch. }\end{array}$ \\
\hline
\end{tabular}

Table 5.2: Showing organoleptic characters of finished product

\begin{tabular}{|l|l|l|}
\hline Sr.no. & Organoleptic Characters & Observation \\
\hline 1 & Shabda & Mrudu \\
\hline 2 & Sparsha & Brownish \\
\hline 3 & Rupa & Katu, Tikta \\
\hline 4 & Rasa & Mixed smell of Tulsi, ardrak and Dhattur. \\
\hline 5 & Gandha \\
\hline
\end{tabular}

\section{RESULT:}

Wt. of finished product $-177 \mathrm{gms}$

Wt gain $-27 \mathrm{gms}$

Reason for weight gain - due to extract of Bhavana Dravya

$>$ Dose- 1 Gunja(125mg)

$>$ Anupan - Ardrak swaras

Therapeutic Uses - Sannipatik jwar, Romantika, Galaganda.

\section{DISCUSSION}

TKR (Tribhuvankirti Rasa) has been described in many texts. Composition of formulation mentioned as per reference of Yogaratnakar has been quoted by maximum texts, hence followed in current study. In preparation of TKR, Shodhan of 3 Dravyas have been done, Hingula Shodhan (purification of cinnabar), Tankan Shodhan (Purification of borax) and Vatsanabha Shodhan (purification of Aconite). Hingula Shodhan was done by giving 7 Bhavana of Ardrak Swaras (ginger juice). All ingredients of TKR are Ushna and Ardrak Swaras (ginger juice) is also ushna Gunatmaka, so to enhance Ushna guna of TKR by synergisum, hingula Shodhana was done by $A r$ drak Swaras. Gomutra (cow's urine) is a better media than Godugdha (cow's milk) for Vatsanabha Shodhan as far as toxic alkaloids are concerned. ${ }^{[15]}$ In Pathsanyojan kram (sequence to prepare medicine) of Kharaliya Kalpa, it is mentioned that the drugs should be added in the sequence- Mineral drug - Vishadravya (poisonous drug) if any- Prativisha (antidote) of that Vishadravya - other herbal ingredientsBhavana dravya. So, while preparation of TKR, the sequence followed was: Shuddha hingul- Shuddha vatsanabha- Shuddha Tankan- Suntha churna, pippali churna, Pippalimoola Churna- Tulasi Patra Swaras.

For each Bhavana, about 6 hrs of mardan (trituration) was done. Total $56 \mathrm{hrs}$ mardan (trituration) was done. Total duration needed was 1 month. Weight of final product was increased by 27 gms. Due to extract or starch present in Bhavana dravya, weight of final product was increased.

\section{CONCLUSION}

This study will serve as a guide for those who want to reproduce Tribhuvankirti Rasa in future that provide them with the details on what has to be done at each step of production.

\section{REFERENCES}

1. Chaudhary A, et al, herbomineral formulations (Rasaushadhis) of Ayurveda: an amazing inheritance of ayurvedic pharmaceutics, Anc Sci Life. 2010 Jul.

2. Yogaratnakar

3. Sharma S, Rasatarangini, $11^{\text {th }}$ Ed, Chapter 9, Verse 18-19, Delhi: Motilal Banarasidas, p.202.

4. Sharma S, Rasatarangini, $11^{\text {th }}$ Ed, Chapter 13, Verse 79-81, Delhi: Motilal Banarasidas, p.319. 
5. Sharma P.V, Dravyagun Vigyan, Volume 2, Varanasi: Chaukhambha Bharati Academy, 2020, p. 106-109.

6. Sharma P.V, Dravyagun Vigyan, Volume 2, Varanasi: Chaukhambha Bharati Academy, 2020, p. 331-334.

7. Sharma P.V, Dravyagun Vigyan, Volume 2, Varanasi: Chaukhambha Bharati Academy, 2020, p. 362.

8. Sharma P.V, Dravyagun Vigyan, Volume 2, Varanasi: Chaukhambha Bharati Academy, 2012, p. 278-279.

9. Sharma P.V, Dravyagun Vigyan, Volume 2, Varanasi: Chaukhambha Bharati Academy, 2020, p. 289.

10. Sharma P.V, Dravyagun Vigyan, Volume 2, Varanasi: Chaukhambha Bharati Academy, 2020, p.513-516.
11. Sharma P.V, Dravyagun Vigyan, Volume 2, Varanasi: Chaukhambha Bharati Academy, 2020, p. 500.

12. Sharma S, Rasatarangini, $11^{\text {th }}$ Ed, Chapter 9, Verse12, Delhi: Motilal Banarasidas, p.201.

13. Ibid. Chapter 13, verse 77-78, p.318.

14. Ibid. Ch. 24, Verse 19-22, p.651-652.

15. Arya Neha, et. al. Comparative physico-chemical profile of Vatsanabha (Aconitum ferox, Ranunculaceae) Mula processed through cow's milk, IJRAP, Oct. 2017, 8(5): 217-222.

Images: Showing preparation of TKR

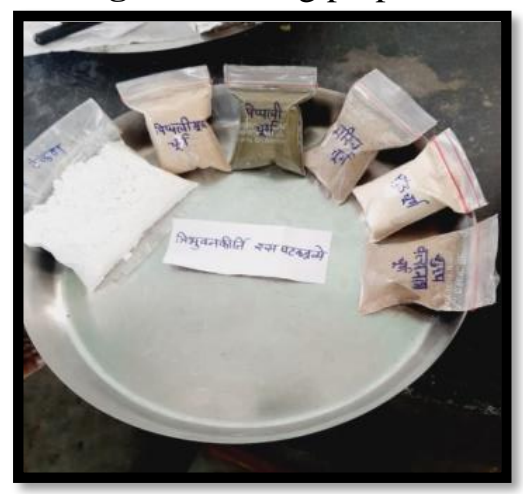

1.Ingredients

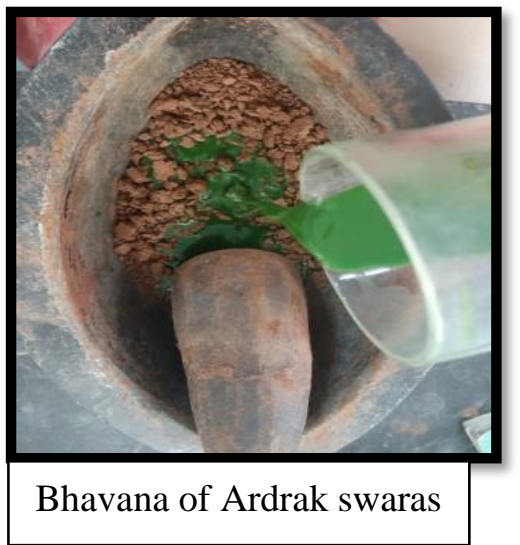

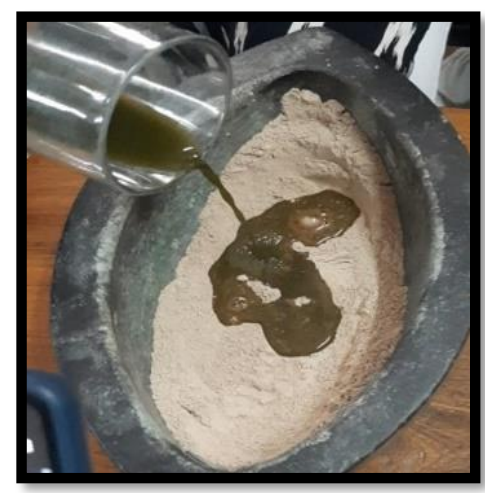

\section{Bhavana of Tulsipatra swaras}

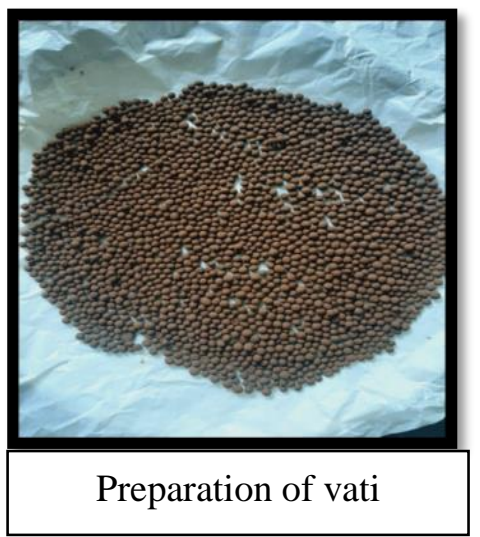

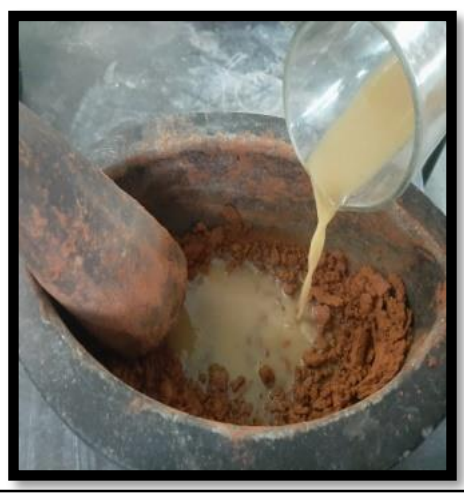

3.Bhavana of Ardrak Swaras

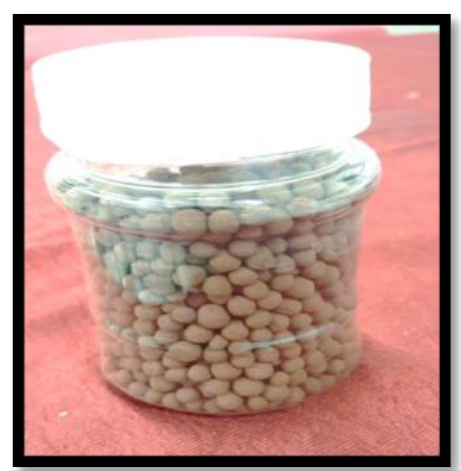

Packed finished drug

\section{Source of Support: Nil}

\section{Conflict of Interest: None Declared}

How to cite this URL: Kirti B \& Ganesh S. Tekale: Pharmaceutical Study Of Tribhuvankirti Rasa: A Herbomineral Formulation. International Ayurvedic Medical Journal \{online\} 2021 \{cited December 2021\} Available from: http://www.iamj.in/posts/images/upload/2914_2919.pdf 